\title{
The Effect of Interdiction on Coca Cultivation in Colombia
}

\author{
Juan Pablo Cote*
}

\begin{abstract}
This paper studies the effect of interdiction on coca cultivation in Colombia. Though directed against intermediate and final stages of cocaine production, this strategy could also have an impact on coca cultivation by affecting monopsonistic activities of illegal groups. My results suggest that different types of interdiction operations have a negative effect on coca crops. In particular, I find that the presence of dismantling of laboratories causes a reduction of 0.003 to 0.006 hectares per squared kilometer in coca cultivation, coca base seizures cause a reduction of 0.003 to 0.008 hectares per squared $\mathrm{km}$, coca leaves seizures cause a reduction of 0.006 to 0.019 hectares per squared $\mathrm{km}$ and cocaine seizures cause a reduction of 0.009 to 0.061 hectares per squared $\mathrm{km}$. I interpret these results as evidence that interdiction is an effective anti-narcotic strategy; however, a cost-benefit analysis is needed to evaluate its convenience over other strategies, like aerial spraying campaigns.
\end{abstract}

Keywords: Interdiction, coca cultivation, causal effect.

JEL Classification: K42, O13, O54 and Q12

*Banco de la República, email: jcotebar@banrep.gov.co. I would like to thank Hernando Zuleta and Daniel Mejía for their guidance at different stages of this project. All remaining errors are mine. 


\title{
El efecto de la interdicción en los cultivos de coca en Colombia
}

\author{
Juan Pablo Cote*
}

Esta versión: Marzo de 2019

\begin{abstract}
Resumen
Este documento estudia el efecto de la interdicción en los cultivos de coca en Colombia. Esta estrategia, pese a estar dirigida contra las etapas intermedia y final del proceso de producción de cocaína, podría tener un impacto sobre los cultivos ilícitos al afectar las actividades monopsonísticas de los grupos ilegales. Los resultados del estudio sugieren que los diferentes tipos de operaciones de interdicción tienen efectos negativos en los cultivos de coca. En particular, encuentro que la presencia de desmantelamientos de laboratorios causa una reducción de 0.003 a 0.006 hectáreas cultivadas por kilómetro cuadrado; las incautaciones de base de coca causan una reducción de 0.003 a 0.008 hectáreas cultivadas por $\mathrm{km}$ cuadrado; las incautaciones de hoja de coca causan una reducción de 0.006 a 0.019 hectáreas cultivadas por km cuadrado, y las incautaciones de cocaína causan una reducción de 0.009 a 0.061 hectáreas cultivadas por km cuadrado. Estos resultados son interpretados como evidencia de que la interdicción es una estrategia efectiva en la lucha contra los cultivos ilícitos; no obstante, se requiere un análisis costo-beneficio para evaluar su conveniencia frente a otras estrategias, como la aspersión aérea.
\end{abstract}

Palabras clave: Interdicción, cultivos de coca, efecto causal.

Códigos JEL: K42, O13, O54 y Q12

*Banco de la República, email: jcotebar@banrep.gov.co. Agradezco a Hernando Zuleta y Daniel Mejía su valíosa ayuda en diferentes etapas del proyecto. Todos los errores restantes son míos. 


\section{Introduction}

Strategies in the war on drugs in the Colombian context have been a controversial topic amongst academics and policy makers. Until 2015, the main strategy in curbing offer of cocaine was eradication of coca crops, particularly through aerial spraying, which reached its peak during Plan Colombia program in 2006 (Mejía, 2016). However, significant research has called into question its effectiveness (Mejía et al., 2015; Moreno-Sánchez, 2003) and has documented its adverse consequences on health (Camacho and Mejía, 2017; Froes Asmus et. al, 2017), welfare (Rozo, 2015), environment (Rincón-Ruiz et al., 2016) and social and institutional outcomes (Garcia, 2011; Felbab-Brown, 2009; Navarrete-Frias \& Thoumi, 2005). This led to the decision at the end of 2015 by the Colombian government to suspend aerial spraying of illicit crops (see EFE, 2015 and El Tiempo, 2015).

A complementary strategy used in the fight against cocaine markets has been interdiction, which includes operations such as cocaine processing facilities destruction (or dismantling of laboratories) and seizures (of coca base, coca leaves and cocaine). These actions are aimed to reduce cocaine offer by attacking intermediate and final stages of its production chain. Interdiction became relatively important since 2004, but has increased significantly since 2015, when dismantling of laboratories and cocaine seizures grew annually by $63 \%$ and $98 \%$, respectively.

Nevertheless, the debate persists. During 2015, 2016 and 2017, coca cultivation increased significantly in Colombia, by about 39\%, 52\% and 17\%, respectively, reaching 171,000 hectares in 2017. Opponents to the suspension of spraying argue that there is causality between this suspension and coca crops increase, and ask for the resuming of aerial spraying campaigns (see, for example, El Espectador, 2016). In fact, US government has also recently asked Colombia to resume aerial spraying campaigns (Semana, 2017), and the new Colombian government has made efforts in this direction (El País, 2018). But, on the other side of the debate, there are arguments that claim that spraying is not an adequate strategy, and that other efforts (including interdiction and and alternative livelihood programs for coca-growing population) can be more effective. In particular, it has been argued that interdiction efforts would be a more effective counternarcotics strategy, given that "they are focused on those stages of production [of cocaine] where the greatest value-added is produced" (Mejía, 2016).

This last argument lies upon the fact that interdiction is properly aimed against stages of production of cocaine that are significant in terms of value-added. However, this strategy can have an effect on coca cultivation by affecting activities of illegal armed groups, who, besides purchasing coca leaf and coca base, participate in the process of cultivation with their involvement and protection. 
There are two main contributions of this paper. On one side, to the best of my knowledge this is the first study to explore the effects of interdiction on coca cultivation. On the other side, conclusions of this study contribute to the debate on the relative effectiveness of different strategies used in war on drugs.

I use a municipal panel with data on coca cultivation, municipalities' characteristics and interdiction and eradication information, from 1999 to 2017. I use Arellano-Bond GMM estimators and conditional differences-in-differences to identify the average effect of interdiction on coca crops in Colombia. My findings indicate that interdiction reduced coca cultivation in the analysed period. In particular, I find that (i) the presence of dismantling of laboratories causes a reduction of 0.003 to 0.006 hectares per squared kilometer in coca cultivation, (ii) coca base seizures cause a reduction of 0.003 to 0.008 hectares per squared $\mathrm{km}$, (iii) coca leaves seizures cause a reduction of 0.006 to 0.019 hectares per squared $\mathrm{km}$ and (iv) cocaine seizures cause a reduction of 0.009 to 0.061 hectares of coca per squared $\mathrm{km}$.

These findings would indicate two things. First, and most obvious, that interdiction has an effect on coca crops. Further research may explore the cost-effectiveness of this strategy. Secondly, evidence presented in this paper indicates that, given the small effectiveness of aerial spraying found by previous studies, interdiction efforts should be considered as a possibly more effective strategy in war on drugs than spraying campaigns.

The rest of the paper proceeds as follows. Section 2 describes a potential channel of the effect of interdiction on coca cultivation. Section 3 presents previous literature on the identification of the effect of the strategies aimed to curb coca cultivation. Section 4 presents the data. Sections 5 and 6 discuss the main results obtained from GMM estimation and conditional differences-in-differences. Section 7 presents a placebo test. Finally, section 8 concludes.

\section{Interdiction and coca cultivation: potential channel of the effect}

I begin by stating some arguments pointing to the fact that interdiction could have an impact on coca cultivation, despite not being addressed against this stage of production. I argue that interdiction can introduce a negative shock in the supply curve of coca leaf by affecting monopsonistic activities of illegal groups supporting coca cultivation and purchasing coca crops. According to UNODC (2016), estimates suggest that about two thirds of farmers who grow coca sell coca leaves directly to cocaine producers, while the other third transform coca leaves into coca base and sell it. Mejía and Rico (2011) report that existing evidence suggests 
that the market of coca leaves and coca base most probably behaves as a monopsony, in which the only buyer is the illegal armed group in control of the territory (FARC, a paramilitary group or another group, depending on the region). Moreover, Mejía and Restrepo (2016) report that cultivation and (eventual) processing of coca crops "is carried out by farmers, with the protection and direct involvement of illegal armed groups" (p. 8). Interdiction efforts act against the group that exerts this support and protection, since they affect its operations of transformation of coca crops (or coca base) into cocaine and drug trafficking in a region through enforcement. Thus, this strategy may introduce a shock into the process of coca growing (and its potential transformation into coca base), which has a high level of uncertainty (Mejía and Rico, 2011). As a consequence, coca growers could expect lower profits from cultivating coca crops (given that they receive less protection or involvement from illegal groups). The probable result is less incentives for cultivation and a consequent lower supply of coca leaves, at least at the local level.

Note that this argument would imply an increase in the price of coca leaf. This can be seen in Figure 1, which shows a standard monopsony optimal behaviour with linear supply and marginal product value, as an initial movement from equilibrium point $A$ to $B$, generated by a lower supply and a consequent higher marginal cost of coca crops. In spite of this expected effect, however, UNODC data shows that prices of coca leaf in Colombia have remained relatively stable since 2006 (see Figure 2). A possible explanation for this is that, added to the shift that it introduces in the supply curve of coca crops, interdiction could also shift marginal product value curve of the monopsonist in the market of coca crops. As a monopsony, prices of coca leaf and coca base are determined locally by the illegal armed group who buys them. In this sense, if interdiction is aimed to attack intermediate and final stages of cocaine production, the monopsonist activity is harmed directly by this strategy. The more interdiction there is, the smaller are expected gains from production in this illegal market (since, for example, dismantling of a laboratory or seizures imply a negative shock on productivity or inputs used for cocaine production). One could argue that if this is the case, the monopsonist could face a marginal product value curve (assuming that it is downward sloping) that is now displaced to the left with respect to the original one, as a result of interdiction. As a result, the effect of a higher coca leaf price is at least partially counteracted by this mechanism, represented in Figure 1 as a movement to final equilibrium C. 


\section{Previous literature on evaluation of policies against coca cultivation}

This paper is related to the branch of economic literature on the effects of strategies aimed at reducing coca cultivation. Since aerial spraying has been the main anti-drug strategy (Mejía et al., 2015), it has also been the most evaluated policy in this context. The main challenge in such studies is to address endogeneity issues caused by the fact that these treatments are not assigned randomly (e.g., spraying is higher in areas with more coca crops), thus generating simultaneity bias in OLS estimates.

In one of these studies, Reyes (2011) uses a panel dataset from 2001 to 2006 to estimate the effect of eradication on coca cultivation, by exploiting exogenous sources of variation in eradication. He uses an instrumental variables approach. The instruments used reflect differences in the expected costs of eradication, as aircrafts used for spraying get far from the area in which Antinarcotics Police can protect them from being shot down by illegal groups. His results indicate that eradication programs (both aerial and manual) are not effective in reducing coca crops: the estimated causal effect of an increase of $1 \%$ in eradication is an increase of about $1 \%$ in coca cultivation.

Bogliacino and Naranjo (2012) use municipal data from 2000 to 2008 and instrument spraying with crime rate and forced displacement. They consider these sources of variation in spraying exogenous, since politicians have an incentive to show response to increases in these variables -for electoral reasons- fastly, and one way to do so is devoting sources to spraying campaigns. Their results suggest that spraying is not effective in reducing coca crops and, in fact, increase them.

Another body of literature finds a negative effect of aerial spraying on cultivation, but also finds evidence of its important side effects or its cost-ineffectiveness. Rozo (2015) uses a data set with 1 squared $\mathrm{km}$ information on the location of coca crops from 2000 to 2010, and identifies the effect of spraying by exploiting the exogenous variation created by restrictions to spraying in natural parks and indigenous territories. Her results indicate that spraying has a small effect on coca cultivation, but it has an important impact on several socio-economic indicators in the treated areas. In this same line, Abadie et al. (2015), who evaluate the effects of Plan Colombia (an US aid package including financial support for eradication campaigns) find that aerial spraying of coca crops reduces cultivated area, but also increases guerilla-led violence.

Finally, Mejía et al. (2015) exploit variation caused by a diplomatic friction between Colombia and Ecuador that generated suspension of spraying in a $10 \mathrm{~km}$ band around the 
border with Ecuador in 2006. They use a fuzzy regression discontinuity design and conditional differences-in-differences to estimate the effect of spraying on coca cultivation. Their results indicate that spraying has a negative and significant impact on coca crops, but also that the sizes of these effects are not enough to make aerial spraying a cost-effective strategy in war on drugs.

\section{Data}

I employ a municipal panel data set from 1999 to 2017 on coca crops, interdiction and eradication data, and municipal characteristics. The data on coca cultivation by municipality is collected by the United Nations Office for Drugs and Crime (UNODC). Coca census are developed annually since 1999 via satellite at the end of each year. Interdiction data comes from the Colombian Drugs Observatory (ODC), whose source is the Ministry of Defense of Colombia. This data consists of the number of cocaine processing facilities destroyed and the amount (in kilograms) of coca base, coca leaves and cocaine seized each year at the municipality level. It includes terrestrial, maritime and aerial seizures (restricted to the national territory for the purposes of this study) ${ }^{1}$. Data of aerial spraying and manual eradication also come from ODC Ministry of Defense. Data on municipal characteristics included in regressions come from a municipal panel built by CEDE (Research Center on Economic and Development Studies at Universidad de los Andes). Table 1 presents descriptive statistics for the variables used in the estimations. In all, the estimation sample has 1,103 municipalities.

Figure 3 presents the evolution of hectares with coca cultivation in Colombia, as well as aerial spraying, manual eradication and interdiction series. During 2012 and 2013, coca cultivation reached historical minimums of about 48,000 hectares. However, since 2014 there has been an important increase in coca cultivation to levels of about 171,000 hectares in 2017. Aerial spraying reached its peak in 2006, and manual eradication did in 2008. As to interdiction, cocaine processing facilities destruction and cocaine seizures have increased importantly since 2014, reaching historical levels in 2016 (of about 4,800 dismantled laboratories and 280,000 kilograms of cocaine seized), while the volume of coca base seized reached its highest level in 2010. Figure 4 reports the evolution of these variables.

From Figure 3, panels A and B, there are two evident things to consider. On one hand, as

\footnotetext{
${ }^{1}$ Maritime and aerial interdiction operations are important in the case of cocaine seizures. According to the Colombian Drugs Observatory (UNODC, 2016), during 2015 about $25 \%$ of total cocaine seizures (in volume) in the national territory of Colombia were terrestrial. This is due to the fact that maritime seizures are by much the largest in weight and represent enormous amounts of cocaine (UNODC, 2015). As discussed later, the estimated effect of this form of interdiction should be attributable to seizures taking place near the cultivation place (municipality), that is, mostly to this $25 \%$ of total cocaine seizures.
} 
noted by Zuleta (2016), there is no evident correlation between the series of forced eradication (both aerial and manual) and the evolution of coca cultivation. In fact, as stated by this author, coca cultivation decreased between 2008 and 2012, and also did aerial spraying and manual eradication. Thus, it seems that the conclusion that the increase in coca cultivation observed since 2014 is a consequence of the reduction and later suspension of aerial spraying does not stand solidly. Nonetheless, as reported before, there are several voices arguing in support of the effectiveness of eradication in curbing coca cultivation. On the other hand, it can be noted that the effectiveness attributed to aerial spraying campaigns between 2000 and 2006 could be linked to the increase in interdiction (dismantling of laboratories and seizures) during the same period. Moreover, the fall in cultivation between 2008 and 2012 also coincides with a period in which the intensity of interdiction remained relatively stable. These elements motivate the aim of this paper: the evaluation of the effects of interdiction strategies on coca cultivation in Colombia.

\section{GMM dynamic panel estimations}

It is important to control for potential sources of variation in cultivated hectares that could confound estimates when identifying the effects of interdiction on coca cultivation. Firstly, cultivation is not random, and this makes necessary to control for municipal characteristics that can be related to it, including invariant characteristics (through municipal fixed effects). Aerial spraying and manual eradication may also have an impact on coca cultivation. Finally, there can be dynamic linkages in municipal coca cultivation. These elements are considered by estimating models of the form:

$$
Y_{i t}=\alpha+\beta Y_{i, t-1}+\delta I_{i t}+X_{i t}^{\prime} \theta+\gamma_{1} S_{i t}+\gamma_{2} E_{i t}+\sigma_{t}+\varepsilon_{i t}
$$

where $Y_{i t}$ are hectares of coca cultivation in municipality $i$ in year $t, I_{i t}$ is some measure of the intensity of interdiction, $X_{i t}$ is a set of municipal covariates (including population density, rurality index and total transfers from central government per capita), $\sigma_{t}$ are year fixed effects and $\varepsilon_{i t}=\mu_{i}+v_{i t}$. I also control for aerial spraying $\left(S_{i t}\right)$ and manual eradication $\left(E_{i t}\right)$. Including the lagged value of the dependent variable as a regressor allows to control for potential persistence in coca cultivation. The coefficient of interest in these models is $\delta$, which captures the effect of interdiction on coca cultivation.

However, estimation of (1) by OLS would lead to inconsistent estimates, since $Y_{i, t-1}$ and $\varepsilon_{i t}=\mu_{i}+v_{i t}$ are correlated by construction of the model. Fixed effects estimator is inconsistent as well, since for fixed $T, \operatorname{plim} \operatorname{Cov}\left(Y_{i t}^{*}, v_{i t}^{*}\right) \neq 0$ for the modified model in 
which variables with '*' are deviations from individual means (Greene, 2008). Furthermore, there are endogeneity issues that arise from the fact that interdiction, spraying and manual eradication are not assigned randomly: they are more intense in municipalities with (more) presence of coca cultivation.

For these reasons, I implement Arellano and Bond (1991) GMM estimator, designed for panel analysis in situations with small $T$ and large $N$ (few time periods and many individuals), dynamic models (left-side variable depends on its own past realizations), a linear model in parameters, independent variables that do not satisfy strict exogeneity, and individual effects (Roodman, 2006). In this case, I instrument differences with lagged levels of the dependent variable, and choose adequately the order of lags to ensure exogeneity of instruments. Furthermore, this methodology allows for the inclusion of external instruments. I include external instruments that explain both interdiction and eradication (manual and aerial), namely: (i) the interaction between the minimum distance of the municipality to a military base, and the US military aid to Colombia in real billions of dollars of 2010 (following Rozo, 2015) as reported by the Security Assistance Monitor, (ii) the interaction of the percentage of municipal area outside protected areas and US military aid to Colombia and the interactions of these variables with year dummy variables. As can be seen, Hansen tests provide evidence that these are exogenous instruments (the null hypothesis of endogeneity of instruments is always rejected at $5 \%$ of significance).

Table 2 presents the results of estimating model 1 by GMM using Arellano-Bond approach. The results in each column correspond to different measures of the intensity of interdiction included in the estimations. Column 1 presents estimates of the effect of dismantling of laboratories. Column 2 presents estimates of the effect of seizures of coca base, column 3 does it for seizures of coca leaves, column 4 for seizures of cocaine and column 5 for the three types of seizures. Finally, column 6 presents estimates of the effect of all these measures of interdiction when they are all included as regressors.

These estimates show that, on average, an increase of one cocaine processing facility destroyed causes a reduction of about 8.7 to 10.1 hectares of coca cultivation in the municipality within the subsequent two years. This effect is around $10 \%$ to $11 \%$ of mean value of coca cultivation. These results also suggest that an additional kilogram of coca base seized generates a reduction of about 0.2 to 0.4 hectares of coca cultivation within the subsequent two years. I also find that on average, an additional kilogram of coca leaf seized reduces coca cultivation in about 0.02 hectares two years later. In all, these results suggest that the effect of interdiction on coca cultivation is lagged rather than immediate.

Finally, I do not find any strong evidence that cocaine seizures reduce coca cultivation. If the mechanism of the effect is the one discussed in Section 2 (interdiction generating a lower 
demand for coca leaves locally), the estimated effect of cocaine seizures on coca cultivation should be attributable to terrestrial seizures, which in 2015 represented about a quarter of total cocaine seizures (in volume). The remaining $75 \%$ of these seizures can take place in a municipality different to the cultivation place, since they are maritime or aerial. The fact that location of cocaine seizures does not always match coca cultivation places could be introducing biases in this estimate, and could be behind the fact that the coefficient for contemporary cocaine seizures is positive and statistically significant in two of the specifications (see Table 2).

In order to check the robustness of these results, I run a second set of regressions in which all variables of interest are in logarithms. In fact, I take the transformation $\log (x+1)$ in order to avoid indetermination of the function whenever the variable $x$ is equal to zero. These results are presented in Table 3. Given the transformation made, the parameters can be almost understood as elasticities. These results indicate that an increase of $1 \%$ in the number of cocaine processing facilities destroyed seems to cause a reduction of about $0.2 \%$ to $0.3 \%$ on hectares of coca cultivation in the municipality within the subsequent two years. They also suggest that an increase of $1 \%$ in the amount of coca base seized generates a reduction of about $0.5 \%$ of the area cultivated with coca within the subsequent two years. Interestingly, cocaine seizures appear to have an effect on coca crops (elasticity is about -0.2) in one of the specifications and I did not find any positive significant coefficient for this variable (possible bias in Table 2). However, in this case I do not find strong evidence that seizures of coca leaves reduce coca cultivation.

As a further robustness check, I follow Abadie et al. (2015) and estimate model 1 for municipalities conditioned on having had a positive amount of coca in 1999 (the first year of my sample). I do this in order to find out whether my estimates are robust using a specification that is much less zero-inflated. As shown in Table 4, there are 91 municipalities that had coca in 1999. By 2017 coca persisted in 82 of those (about 90 percent).

According to Table 4, each additional laboratory dismantled in the municipalities that presented coca in 1999 causes a reduction of about 9.2 to 11.5 hectares of cultivated area within the subsequent two years. Also, an additional kilogram of coca leaves seized would cause a decline of 0.01 to 0.03 in coca cultivation within the subsequent two years. In this case, I find more consistent evidence of the effect of cocaine seizures on coca cultivation, but there are also results that may respond to the bias discussed before. Finally, I do not find any evidence on the effect of coca base seizures on coca cultivation.

As stated by Abadie et al. (2015), it is important to mention that these estimates should be interpreted as local effects, since I do not take into account potential general equilibrium effects (like the possibility of coca growers moving their crops to other municipalities). 
Moreover, an additional possible consequence of interdiction is that coca growers replant in the same municipality near the location where interdiction took place, or at some distance from it (for example, in more frontier areas of the municipality) and with more atomization, attempting to hide crops. This last possibility is addressed in Table 4. These results can be interpreted to what extent the regions in which coca was present in 1999 experienced successful decline in cultivated area due to interdiction. I focus on the effect of laboratories dismantling given its robustness. According to Table 4, the estimated effect of an additional laboratory destroyed is larger than the benchmark 8.7 to 10.1 hectares (Table 2). These results suggest that interdiction was more effective in those municipalities with coca crops in 1999, and provide evidence against the phenomenon of coca growing again in the same municipalities where interdiction took place. Furthermore, given the evidence that aerial spraying has been ineffective due to coca replanting after eradication efforts (Abadie et al., 2015), these results support the idea that interdiction would be a more effective strategy for curbing illegal crops.

In sum, it can be stated that the above results are in line with the hypothesis derived from literature on the microeconomics of the cocaine market: interdiction affects monopsonistic activity of illegal armed groups who demand coca leaves and coca base, and ends up reducing coca farmers incentives to grow coca.

Another relevant result for discussion is that I do not find a robust effect of aerial spraying on coca cultivation. Although the coefficient of this variable is always negative, it is only significant at the $90 \%$ level in two of the specifications of Table 2. This is consistent with the narrative that spraying is not an effective strategy in curbing coca cultivation, as stated by previous studies (Mejía et al., 2015). Manual eradication appears to have an effect on cultivation, but it is not robust to all estimations. These results can be added to the evidence that calls into question the hypothesis that the increase of coca cultivation since $2015^{2}$ was caused by the reduction and posterior suspension of spraying during those years. More generally, they also argue against the argument that there is a strong causality between spraying and coca crops.

However, other factors could explain this increase. First, recent exchange rate dynamics could have affected coca cultivation during the last two or three years, since cocaine is an exported product and Colombian peso depreciation (which began on July 2014) is an incentive to increase coca production. Moreover, peace process with FARC could also have had an impact on cultivation, as long as its conclusion in 2016 could have given incentives to farmers and growers of coca crops to benefit from the possible programs of alternative

\footnotetext{
${ }^{2}$ According to UNODC data, between 2015 and 2017 coca cultivation grew about $78 \%$.
} 
development and could have motivated an increase in cultivation (UNODC, 2017; El País, 2017). Recall that Table 2 includes year fixed-effects in all specifications, that control for any shock that may affect simultaneously all municipalities and therefore provide a way to test these hypothesis. The coefficients on dummies for 2016 and 2017 (not reported to save space) suggest that any of these events (depreciation or peace process) might, in fact, have had an effect on coca crops, since they are positive and significant at the $5 \%$ level in three of the specifications. As long as these estimates are consistent, this would imply that the recent increase in coca cultivation has additional explanations not related to the dynamic of strategies against illicit crops (e.g., the suspension of aerial spraying), for which I control explicitly.

One final question of interest is whether different counternarcotic strategies are substitutable or complementary. In order to do so, I estimate regressions that include interactions between interdiction and aerial spraying, and interactions between interdiction and manual eradication. Let $Y_{i t}$ be the hectares of coca cultivation in municipality $i$ in year $t$. Strategies $\mathrm{A}$ and $\mathrm{B}$ are complementary if strategy A reinforces the negative effect of strategy B (or vice versa) on coca cultivation, that is, if

$$
\frac{\partial Y_{i t}}{\partial\left(A_{i t} \times B_{i t}\right)}<0
$$

Similarly, strategies A and B are substitutable if the inequality in (2) is >. Notice that these definitions assume that both $\mathrm{A}$ and $\mathrm{B}$ have negative individual partial effects on $\mathrm{Y}$. Table 5 presents the results of these estimations. Each column represents a different type of interdiction. The most robust result I find is some degree of substitutability between interdiction (namely, laboratories dismantling and coca leaves seizures) and manual eradication. However, the size of such effects is small when compared to the estimated base effects of these interdiction types. A possible interpretation for this result is that interdiction might be more effective in places where there have not been eradication efforts before, since these latter tend to generate spreading of coca crops (Abadie et al., 2015) and therefore can hinder the mechanism described in Section 2.

\section{Conditional differences-in-differences approach}

In this section, I follow Mejía et al. (2015) and implement a conditional differences-indifferences strategy to estimate the causal effect of interdiction on coca cultivation. Let now $Y_{i t}$ be the hectares with coca crops per squared kilometer in municipality $i$ in year $t$. Figure 5 plots the difference in this variable between municipalities with and without interdiction 
for each year. As can be seen, there are unbalanced dynamics in cultivation that may bias a simple difference of means between both groups of municipalities.

Let $T_{i t}=1\left\{\exists \tau \leq t \mid I_{i \tau}>0\right\}$ for a given measure of interdiction $I_{i t}$. Let also $\overline{Y_{i t}}$ be the average cultivation in municipality $i$ from 1999 to $(t-1)(t \geq 2000)$. I am interested in estimating the treatment effect of $T_{i t}$ on $Y_{i t}-\overline{Y_{i t}}$. Estimating this effect as a difference of means would lead to biased results since, as shown in Figure $5, T_{i t}$ is correlated with $Y_{i t}$. Instead, I assume the following conditional independence assumption:

$$
Y_{i t}-\overline{Y_{i t}} \perp T_{i t} \mid Z_{i},\left\{Y_{i t^{\prime}}\right\}_{t^{\prime} \leq t}
$$

This assumption states that having conditioned on the history of cultivation in a municipality $\left(\left\{Y_{i t^{\prime}}\right\}_{t^{\prime} \leq t}\right)$ and municipality covariates $Z_{i}$ (including a polynomial in altitude and department fixed effects), $Y_{i t}-\overline{Y_{i t}}$-the dependent variable of interest ${ }^{3}$ - is orthogonal to the treatment -interdiction-.

I exploit condition 3 in two ways to estimate the effect of interdiction on coca cultivation. First, I estimate the model:

$$
Y_{i t}-\overline{Y_{i t}}=\alpha_{t}+\beta_{t} T_{i t}+\sum_{t^{\prime} \leq t} \theta_{t^{\prime}} Y_{i t^{\prime}}+Z_{i}^{\prime} \Gamma+\varepsilon_{i t}, \forall t \geq 2009
$$

In this regression, $\beta_{t}$ identifies the effect of interdiction during year $t$ under the assumption that conditional expectation of the outcome is linear in the covariates. I take 2009 as the starting year for these estimations because it is the first year in which treated and control groups have similar sizes for different measures of interdiction. Columns 1, 3, 5 and 7 of Table 7 present the regression estimates for different measures of interdiction (laboratories dismantling, seizures of coca base, seizures of coca leaves and seizures of cocaine, respectively). I present separately the estimates of $\beta_{t}$ by year. They show that laboratories dismantling reduced coca cultivation in the period 2011-2015, and that the effect of this treatment is a reduction of 0.008 to 0.021 hectares per squared kilometer. These estimates also show that, in a similar period, the effect of seizures of coca leaves is a reduction of 0.013 to 0.029 hectares per squared $\mathrm{km}$ in cultivation. Finally, I find that the effect of cocaine seizures, beginning in 2013, is a reduction of 0.009 to 0.022 hectares per squared $\mathrm{km}$ in cultivation. I do not check for equal trends because pre and post-treatment years are different for each municipality (depending on the year in which interdiction began, if it did).

In order to relax the assumption that conditional expectation of cultivation is linear in the covariates, I follow a second strategy in which I control non-parametrically for the propensity

\footnotetext{
${ }^{3}$ Following Mejia (2014), I employ the change in cultivation instead of its level to remove any invariant difference between municipalities not captured by the conditioning set.
} 
score $p_{i t}=P\left[T_{i t}=1 \mid Z_{i},\left\{Y_{i t^{\prime}}\right\}_{t^{\prime} \leq t}\right]$. I match municipalities for each year $t$ (from 2005 to 2017) based on the estimates $\hat{p_{i t}}$, estimated for each year using probit models not reported to save space.

In columns 2, 4, 6 and 8 of Table 7 (presenting results for laboratories dismantling, seizures of coca base, seizures of coca leaves and seizures of cocaine, respectively) I do Kernel matching on the propensity score. I present estimates of the standard errors assuming that the propensity score is known ${ }^{4}$. These estimates reveal a negative effect of all interdiction measures considered on coca cultivation. The estimated effect of laboratories dismantling is a reduction of 0.003 to 0.006 hectares per squared kilometer. In the case of coca base seizures, the estimated effect is a reduction of 0.003 to 0.008 hectares per squared $\mathrm{km}$. As for coca leaves seizures, the estimated effect is a reduction of 0.006 to 0.019 hectares per squared $\mathrm{km}$. Finally, in the case of cocaine seizures, the estimated ATT is a reduction of 0.009 to 0.061 hectares per squared $\mathrm{km}$. These results suggest that the linear controls were not capturing enough difference in cultivation dynamics, since they change importantly relative to the ones in odd columns.

Interestingly, once data is weighted by the propensity score, most of the estimates of $\beta_{t}$ for $t=2015,2016,2017$ are negative and significant at 10\% level. These are also the years in which some interdiction operations reached their peaks (see Figure 4). I interpret this result as evidence that even in years in which coca crops grew importantly, interdiction was effective in curbing coca cultivation.

\section{Placebo test}

As a last robustness check on my results I estimate a placebo test using the one-year lead of different measures of interdiction as treatment on the dependent variable. These models are similar to the ones presented in Section 5. Since coca cultivation should only be affected by past interdiction, future interdiction is a fake treatment and no significant effect is expected. Results for this test are presented in Table 6, and they suggest that none of these measures of future interdiction have an impact on coca crops.

\footnotetext{
${ }^{4}$ I keep these because, as stated by Mejía et al. (2015), it is not clear if bootstrapping standard errors produces consistent estimates or not.
} 


\section{Concluding remarks}

In this paper I explored the effect of interdiction on coca cultivation in Colombia during the period 1999-2017. The main motivation for the aim of this study is a potential channel through which interdiction could have an impact on coca growers incentives to cultivate coca by affecting monopsonistic operation of illegal groups who protect and support their activities.

The contribution of this paper lies first in providing evidence on an unexplored question, which is whether interdiction has an impact on coca cultivation, by means of strategies that aim to adequately address endogeneity concerns.

I use an Arellano-Bond GMM approach to estimate a linear model in which I control for persistence of coca crops and municipality fixed effects, and a conditional differences-indifferences approach that compares similar municipalities with and without interdiction to identify the causal effect of this variable on coca cultivation. Both methodologies suggest that interdiction has a negative impact on coca crops. In particular, I find that dismantling of laboratories reduce coca cultivation by about $10 \%$ of mean value of coca cultivation (GMM estimates) or 0.003 to 0.006 hectares of coca per squared kilometer (conditional differences in differences estimate). Also, I find that coca base seizures cause a reduction of 0.003 to 0.008 hectares per squared $\mathrm{km}$, coca leaves seizures cause a reduction of 0.006 to 0.019 hectares per squared $\mathrm{km}$ and cocaine seizures cause a reduction of 0.009 to 0.061 hectares of coca per squared $\mathrm{km}$.

These results indicate that interdiction has an effect on coca crops, though further research is needed to evaluate the cost-effectiveness of this strategy. However, given the evidence on the small effectiveness of aerial spraying found by previous studies (as well as its adverse consequences on several social and individual outcomes), interdiction efforts should be considered as a possibly more effective strategy in war on drugs than spraying campaigns.

\section{References}

[1] Abadie, A., Acevedo, M., Kugler, M. \& Vargas, J. (2015). Inside the War on Drugs: Effectiveness and Unintended Consequences of a Large Illicit Crops Eradication Program in Colombia. Working paper.

[2] Arellano, M. \& Bond, S. (1991). Some tests of specification for panel data: Monte Carlo evidence and an application to employment equations. Review of Economic Studies, 58, $277-97$. 
[3] Bogliacino, F. \& Naranjo, A. (2012). Coca Leaves Production and Eradication: A General Equilibrium Analysis. Economics Bulletin, 32(1), 382-397.

[4] Camacho, A. \& Mejía, D. (2017). The Health Consequences of Aerial Spraying of Illicit Crops: The Case of Colombia. Journal of Health Economics, 54, 147-160.

[5] Colombian Drugs Observatory (ODC). (2016). Reporte de Drogas de Colombia 2016. Available at: http://www.odc.gov.co/Portals/1/publicaciones/pdf/odc-libro-blanco/ ODC0100322016_reporte_drogas_colombia_2016.pdf

[6] EFE. (October 2nd 2015). Ordenan oficialmente suspender la aspersión aérea de glifosato en Colombia. Retrieved from https://www.efe.com/efe/america/sociedad/ordenanoficialmente-suspender-la-aspersion-aerea-de-glifosato-en-colombia/20000013-2727972

[7] El Espectador. (September 3rd 2016). Fiscal general pide reactivar la aspersión aérea de cultivos ilícitos. Retrieved from http://colombia2020.elespectador.com/politica/fiscalgeneral-pide-reactivar-la-aspersion-aerea-de-cultivos-ilicitos

[8] El País. (March 13th 2017). Acuerdo de paz con las FARC contribuyó al aumento de coca: Canciller. Retrieved from http://www.elpais.com.co/proceso-de-paz/pacto-de-paz-conlas-farc-aumento-cultivos-de-coca-en-colombia-admitio-el-gobierno.html

[9] El País. (June 19th 2018). Duque reactivaría la fumigación aérea de narcocultivos. Retrieved from https://www.elpais.com.co/elecciones/elecciones-presidenciales/duquereactivaria-la-fumigacion-aerea-de-narcocultivos.html

[10] El Tiempo. (May 15th 2015). Es oficial: termina era del glifosato en fumigaciones en Colombia. Retrieved from www.eltiempo.com/archivo/documento/CMS-15757420

[11] Felbab-Brown, V. (2009). The Violent Drug Market in Mexico and Lessons from Colombia. BROOKINGS Foreign Policy Paper.

[12] Froes Asmus, C., Camara, V., Raggio, R., Landrigan, P. \& Claudio, L. (2017). Positive correlation between pesticide sales and central nervous system and cardiovascular congenital abnormalities in Brazil. International Journal of Environmental Health Research, $27(5), 420-426$.

[13] Garcia, M. (2011). Cultivos ilícitos, paticipación política y confianza institucional. In: Anti-drug policies in Colombia: Successes, failures and lost opportunities (A. Gaviria and D. Mejia eds). Ediciones UniAndes, Bogota. 
[14] Greene, W. H. (2008). Econometric Analysis. New Jersey: Prentice Hall.

[15] Mejía, D., Restrepo, P. \& Rozo, S. (2015). On the Effects of Enforcement on Illegal Markets: Evidence from a Quasi-experiment in Colombia. World Bank Policy Research Working Paper.

[16] Mejía, D \& Restrepo P. (2016). The Economics of the War on Illegal Drug Production and Trafficking. Journal of Economic Behavior \&3 Organization, 126(PA), 255-275.

[17] Mejía, D. \& Rico, D. (2011). La microeconomía de la producción y el tráfico de cocaína en Colombia. In: Anti-drug policies in Colombia: Successes, failures and lost opportunities (A. Gaviria and D. Mejia eds). Ediciones UniAndes, Bogota.

[18] Mejía, D. (2016). Plan Colombia: An Analysis of Effectiveness and Costs. BROOKINGS Foreign Policy Paper.

[19] Moreno-Sanchez, R., Kraybill, D. \& Thompson, S. (2003). An Econometric Analysis of Coca Eradication Policy in Colombia. World Devopment, 31(2), 375-383.

[20] Navarrete-Frias, C. \& Thoumi, F. (2005). Illegal Drugs and Human Rights of Peasants and Indigenous Communities: The Case of Perú. Managenement of Social Transformations Policy Paper 13.

[21] Reyes, L. (2014). Estimating the Causal Effect of Forced Eradication on Coca Cultivation in Colombian Municipalities. World Devopment, 61, 70-84.

[22] Rincón-Ruiz, A., Correa, H., León. D. \& Williams, S. (2016). Coca cultivation and crop eradication in Colombia: The challenges of integrating rural reality into effective anti-drug policy. International Journal of Drug Policy, 33, 56-65.

[23] Roodman, D. (2006). How to do xtabond2: An introduction to "Difference" and "System" GMM in Stata. Working Paper.

[24] Rozo, S. (2015). On the Unintended Consequences of Anti-Drug Eradication Programs in Producing Countries. Working Paper.

[25] Semana. (June 13th 2017). Trump pide a Colombia que se reanuden fumigaciones con urgencia. Retrieved from https://www.semana.com/nacion/articulo/eeuu-pide-acolombia-a-reanudar-la-aspersion-aerea-de-los-cultivos-de-coca/528490 
[26] United Nations Office on Drugs and Crime (UNODC). (2015). Informe Mundial Sobre las Drogas, Resumen Ejecutivo. Available at: https://www.unodc.org/documents/ wdr2015/WDR15_ExSum_S.pdf

[27] United Nations Office on Drugs and Crime (UNODC). (2016). Monitoreo de territorios afectados por cultivos ilícitos. Available at: https://www.odc.gov.co/Portals/1/ publicaciones/pdf/oferta/censos/OF02012016-censo-cultivos-coca-2015.pdf

[28] United Nations Office on Drugs and Crime (UNODC). (2017). Informe 2016 de la Junta Internacional de Fiscalización de Estupefacientes. Available at: https://www.incb.org/ documents/Publications/AnnualReports/AR2016/Spanish/AR2016_S_ebook.pdf

[29] Zuleta, H. (2016). Coca, cocaína y narcotráfico: Preguntas y retos. Revista CIMCON, 2. 


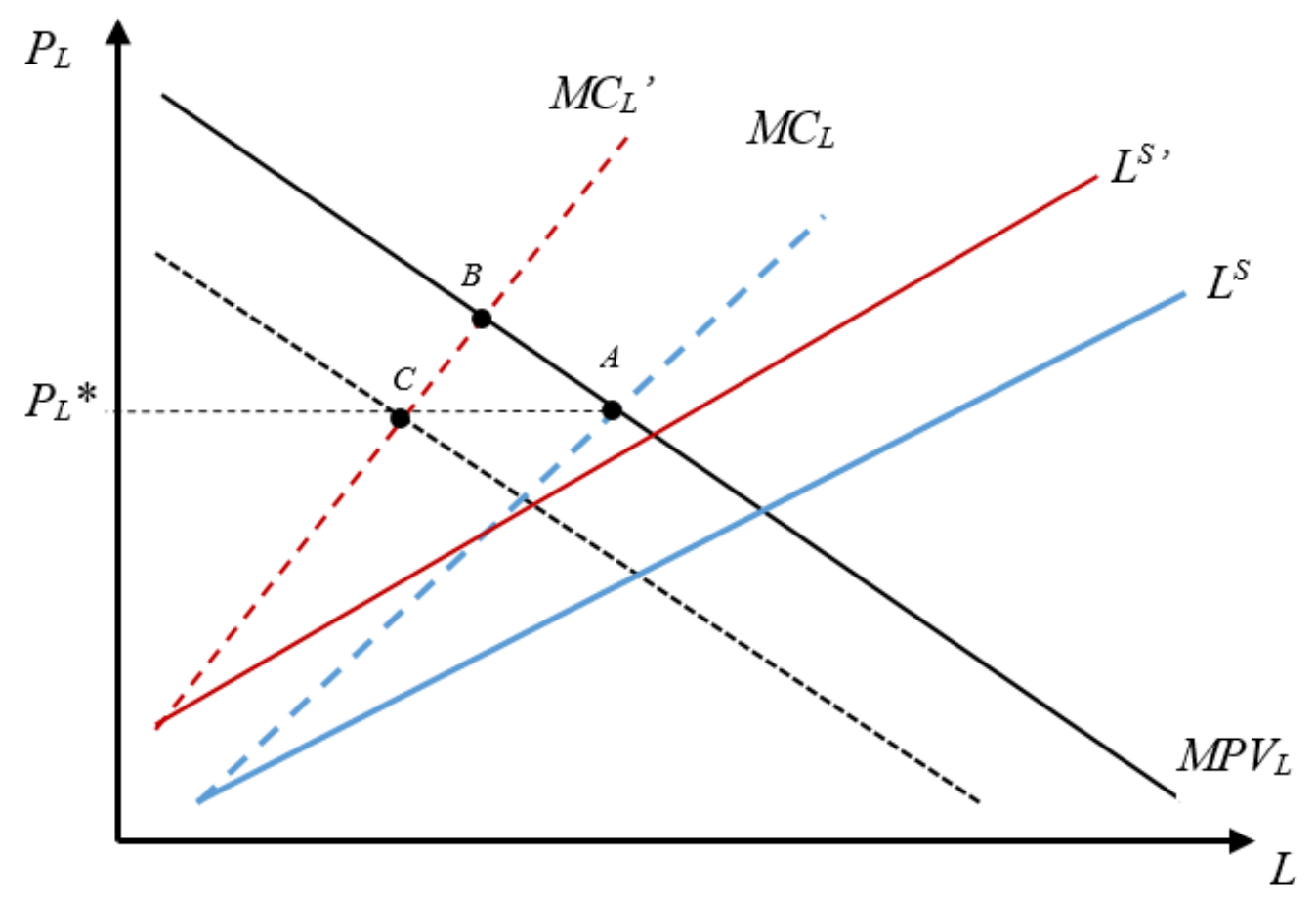

Figure 1: Monopsonistic activity of illegal groups and the effect of interdiction 


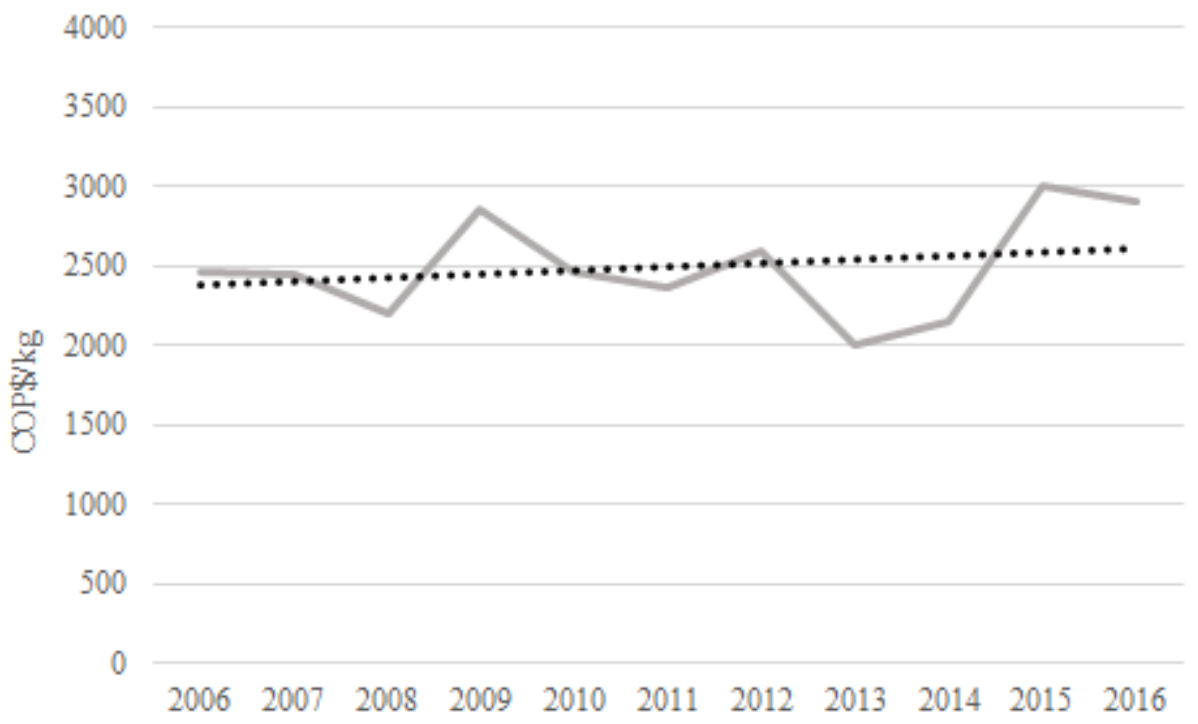

Figure 2: Coca leaf price in Colombia (2006-2015)

Source: UNODC 


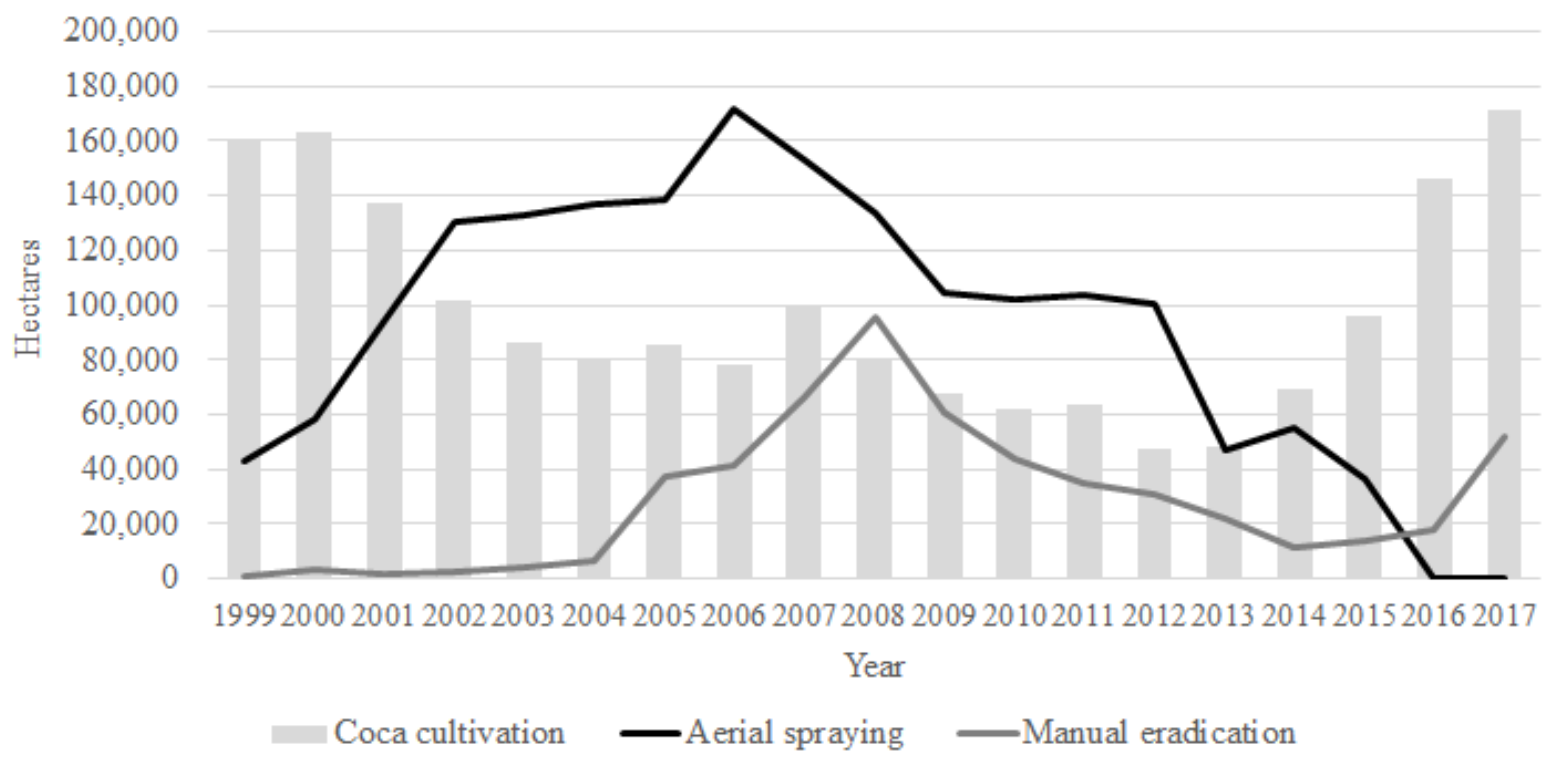

Figure 3: Coca cultivation, aerial spraying and manual eradication in Colombia Sources: ODC and UNODC 


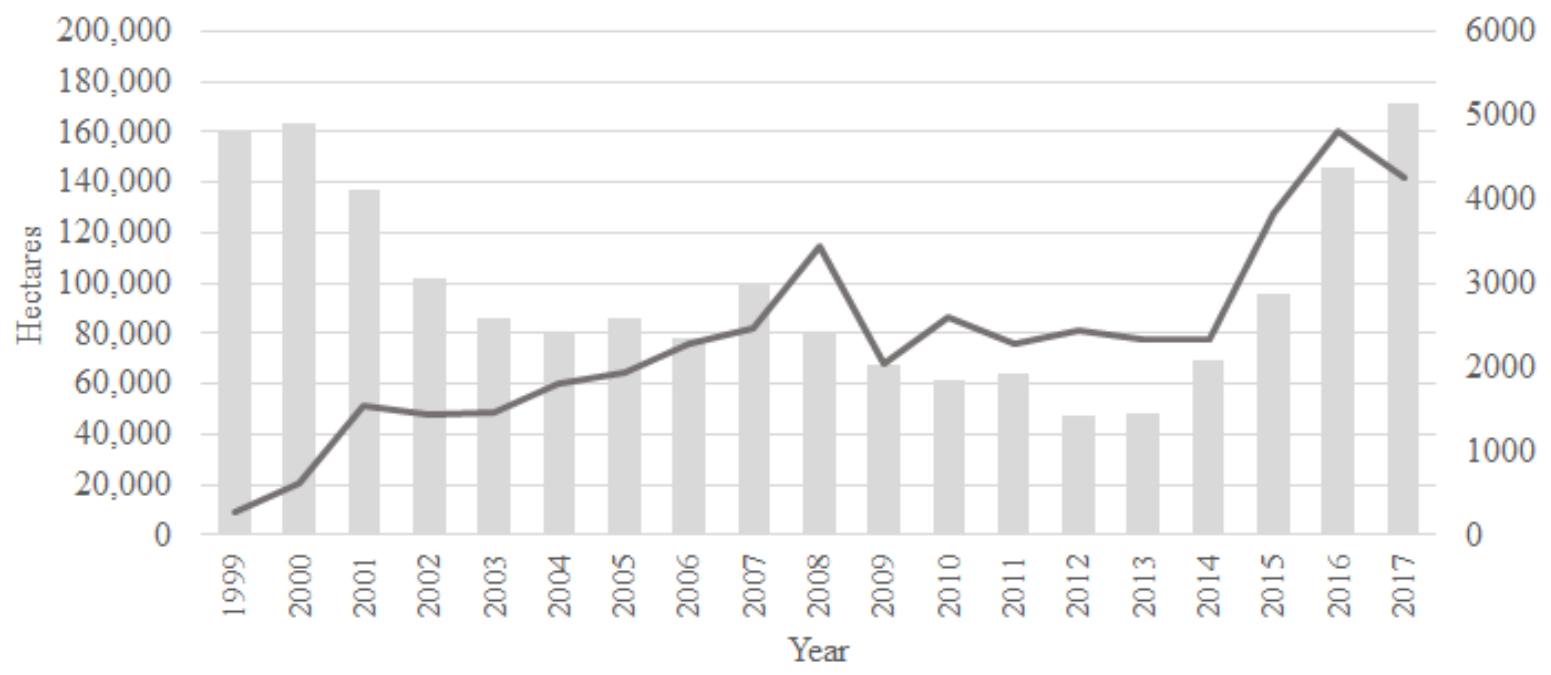

Coca cultivation $\quad$ Number of cocaine processing facilities destroyed (right axis)

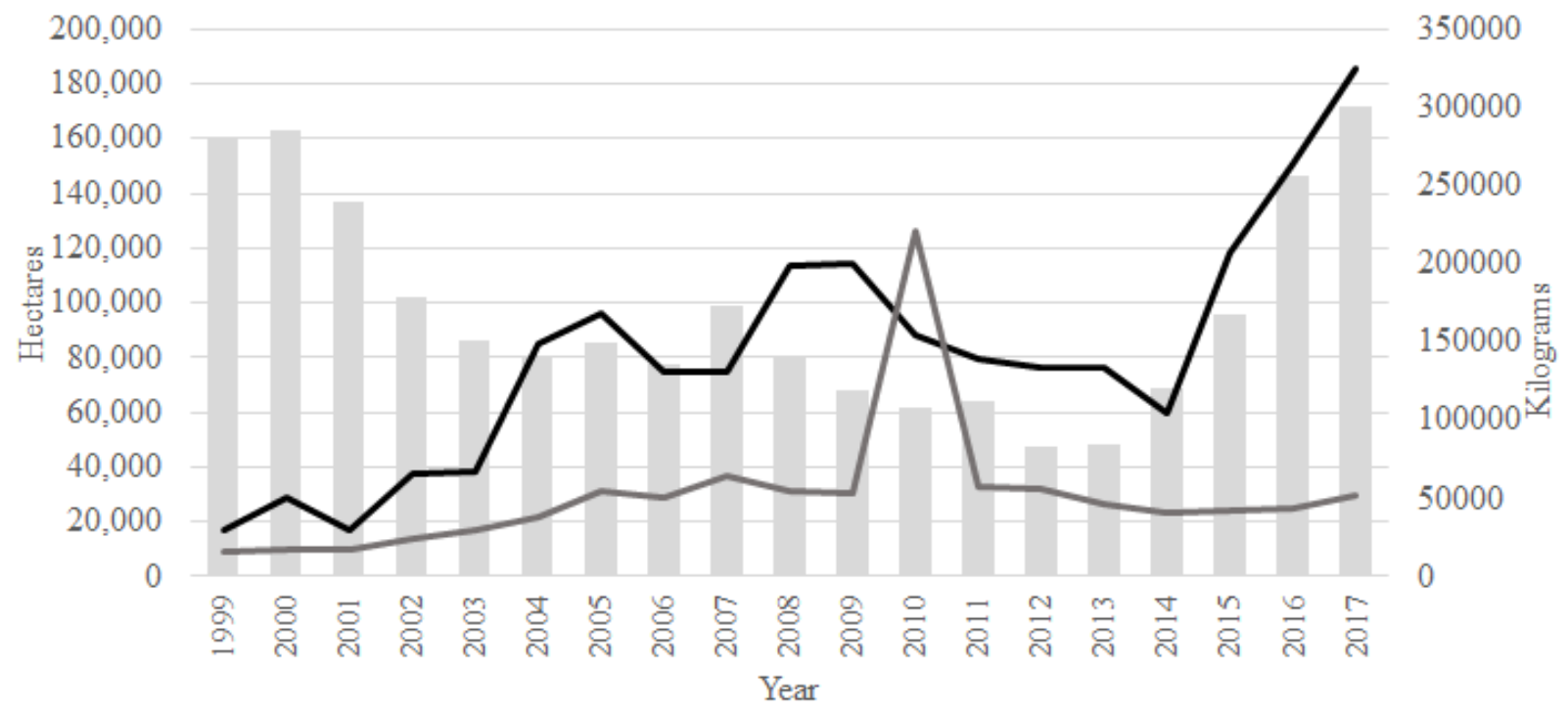

Coca cultivation - Cocaine seizures (right axis) —Coca base seizures (right axis)

Figure 4: Coca cultivation and interdiction in Colombia

Sources: ODC and UNODC 


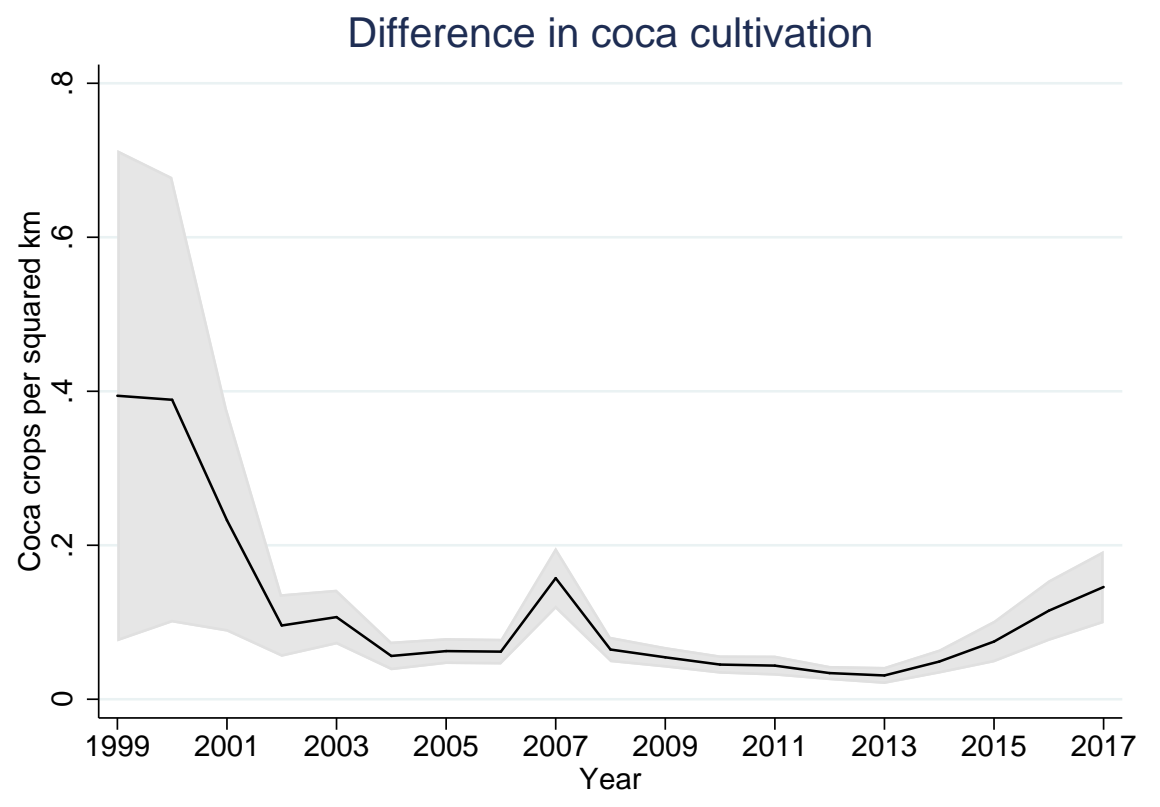

Figure 5: Difference in coca cultivation between municipalities with and without interdiction from 1999 to 2017.

Source: Author's calculations based on ODC and UNODC 
Table 1: Descriptive statistics

\begin{tabular}{lccccc}
\hline \hline Variable & Obs. & Mean & St. Dev. & Min. & Max. \\
\hline Hectares of coca cultivation & 20,927 & 80.7 & 593.2 & 0.0 & $23,148.0$ \\
Number of cocaine processing facilities destroyed & 20,927 & 1.9 & 12.1 & 0.0 & 407.0 \\
Seizures of oca base (in kg) & 20,927 & 46.7 & 534.1 & 0.0 & $40,855.7$ \\
Seizures of coca leaves (in kg) & 20,927 & 633.2 & $6,609.9$ & 0.0 & $446,115.0$ \\
Seizures of cocaine (in kg) & 20,927 & 128.7 & $1,523.6$ & 0.0 & $103,408.5$ \\
Aerial spraying (hectares) & 20,927 & 81.5 & 687.0 & 0.0 & $33,814.0$ \\
Manual eradication (hectares) & 20,927 & 22.1 & 268.3 & 0.0 & $15,265.1$ \\
Population density & 20,927 & 146.1 & 651.7 & 0.1 & $15,935.7$ \\
Rurality index & 20,927 & 0.6 & 0.2 & 0.0 & 1.0 \\
Total (yearly) transfers from CG, per capita & 20,927 & $3.9 \times 10^{5}$ & $4.2 \times 10^{5}$ & 0.0 & $2.7 \times 10^{7}$ \\
Minimum distance to a military base (km)*US Aid & 20,927 & $1.8 \times 10^{7}$ & $3.0 \times 10^{7}$ & 0.0 & $1.2 \times 10^{9}$ \\
Percentage of area outside protected areas*US Aid & 20,927 & $5.4 \times 10^{7}$ & $3.8 \times 10^{7}$ & 0.0 & $1.5 \times 10^{8}$ \\
\hline \hline
\end{tabular}


Table 2: GMM estimates of the effect of interdiction on cultivation

\begin{tabular}{|c|c|c|c|c|c|c|}
\hline \multicolumn{7}{|c|}{ Dependent variable: Hectares of coca cultivation } \\
\hline & $(1)$ & (2) & (3) & (4) & (5) & $(6)$ \\
\hline $\begin{array}{l}\text { Number of coca processing facilities } \\
\text { destroyed at } t\end{array}$ & $\begin{array}{c}2.100 \\
(3.748)\end{array}$ & & & & & $\begin{array}{l}0.450 \\
(3.520)\end{array}$ \\
\hline $\begin{array}{l}\text { Number of coca processing facilities } \\
\text { destroyed at } t-1\end{array}$ & $\begin{array}{l}-7.911 \\
(5.763)\end{array}$ & & & & & $\begin{array}{c}-10.144^{* * *} \\
(3.392)\end{array}$ \\
\hline $\begin{array}{l}\text { Number of coca processing facilities } \\
\text { destroyed at } t-2\end{array}$ & $\begin{array}{c}-8.679^{* *} \\
(3.466)\end{array}$ & & & & & $\begin{array}{l}-7.943 \\
(7.552)\end{array}$ \\
\hline Seizures of coca base (in $\mathrm{kg}$ ) at $\mathrm{t}$ & & $\begin{array}{r}-0.175^{*} \\
(0.092)\end{array}$ & & & $\begin{array}{c}-0.153^{* *} \\
(0.072)\end{array}$ & $\begin{array}{l}-0.103 \\
(0.095)\end{array}$ \\
\hline Seizures of coca base (in $\mathrm{kg}$ ) at $\mathrm{t}-1$ & & $\begin{array}{c}0.023 \\
(0.096)\end{array}$ & & & $\begin{array}{l}-0.036 \\
(0.044)\end{array}$ & $\begin{array}{l}-0.042 \\
(0.086)\end{array}$ \\
\hline Seizures of coca base (in $\mathrm{kg}$ ) at $\mathrm{t}-2$ & & $\begin{array}{l}-0.267^{*} \\
(0.137)\end{array}$ & & & $\begin{array}{c}-0.175^{* *} \\
(0.078)\end{array}$ & $\begin{array}{l}-0.211^{*} \\
(0.114)\end{array}$ \\
\hline Seizures of coca leaves (in $\mathrm{kg}$ ) at $\mathrm{t}$ & & & $\begin{array}{c}0.011 \\
(0.009)\end{array}$ & & $\begin{array}{l}-0.008 \\
(0.008)\end{array}$ & $\begin{array}{c}0.012 \\
(0.010)\end{array}$ \\
\hline Seizures of coca leaves (in $\mathrm{kg}$ ) at $\mathrm{t}-1$ & & & $\begin{array}{l}-0.013 \\
(0.014)\end{array}$ & & $\begin{array}{l}-0.003 \\
(0.011)\end{array}$ & $\begin{array}{c}0.002 \\
(0.017)\end{array}$ \\
\hline Seizures of coca leaves (in $\mathrm{kg}$ ) at $\mathrm{t}-2$ & & & $\begin{array}{c}-0.019^{* *} \\
(0.009)\end{array}$ & & $\begin{array}{l}-0.013 \\
(0.008)\end{array}$ & $\begin{array}{l}-0.004 \\
(0.014)\end{array}$ \\
\hline Seizures of cocaine (in $\mathrm{kg}$ ) at $\mathrm{t}$ & & & & $\begin{array}{c}0.124^{* *} \\
(0.049)\end{array}$ & $\begin{array}{r}0.114^{* *} \\
(0.052)\end{array}$ & $\begin{array}{l}0.091 \\
(0.094)\end{array}$ \\
\hline Seizures of cocaine (in $\mathrm{kg}$ ) at $\mathrm{t}-1$ & & & & $\begin{array}{c}-0.074^{* *} \\
(0.029)\end{array}$ & $\begin{array}{l}-0.058^{*} \\
(0.032)\end{array}$ & $\begin{array}{l}-0.061^{*} \\
(0.037)\end{array}$ \\
\hline Seizures of cocaine (in $\mathrm{kg}$ ) at $\mathrm{t}-2$ & & & & $\begin{array}{l}-0.004 \\
(0.024)\end{array}$ & $\begin{array}{c}0.032 \\
(0.045)\end{array}$ & $\begin{array}{c}0.127^{* * *} \\
(0.041)\end{array}$ \\
\hline Aerial spraying & $\begin{array}{r}-0.144^{*} \\
(0.078)\end{array}$ & $\begin{array}{l}-0.095 \\
(0.085)\end{array}$ & $\begin{array}{l}-0.091 \\
(0.098)\end{array}$ & $\begin{array}{l}-0.138 \\
(0.093)\end{array}$ & $\begin{array}{l}-0.087 \\
(0.107)\end{array}$ & $\begin{array}{l}-0.089 \\
(0.065)\end{array}$ \\
\hline Manual eradication & $\begin{array}{c}-0.154^{* *} \\
(0.068)\end{array}$ & $\begin{array}{c}-0.166^{* * *} \\
(0.060)\end{array}$ & $\begin{array}{c}-0.171^{* * *} \\
(0.062)\end{array}$ & $\begin{array}{l}-0.055 \\
(0.056)\end{array}$ & $\begin{array}{l}-0.073 \\
(0.053)\end{array}$ & $\begin{array}{c}-0.244^{* *} \\
(0.105)\end{array}$ \\
\hline Hectares of coca cultivation at $\mathrm{t}-1$ & $\begin{array}{c}0.960^{* * *} \\
(0.074)\end{array}$ & $\begin{array}{c}0.855^{* * *} \\
(0.170)\end{array}$ & $\begin{array}{c}0.919^{* * *} \\
(0.132)\end{array}$ & $\begin{array}{c}0.625^{* * *} \\
(0.082)\end{array}$ & $\begin{array}{c}0.520^{* * *} \\
(0.129)\end{array}$ & $\begin{array}{c}0.656^{* * *} \\
(0.159)\end{array}$ \\
\hline Municipality FE & Yes & Yes & Yes & Yes & Yes & Yes \\
\hline Year FE & Yes & Yes & Yes & Yes & Yes & Yes \\
\hline Observations & 17,629 & 17,629 & 17,629 & 17,629 & 17,629 & 17,629 \\
\hline Number of municipalities & 1,103 & 1,103 & 1,103 & 1,103 & 1,103 & 1,103 \\
\hline Hansen test p-value & 0.091 & 0.124 & 0.151 & 0.292 & 0.132 & 0.176 \\
\hline
\end{tabular}

Notes: Robust standard errors in parentheses. Estimates with ${ }^{* * *}$ are significant at the $1 \%$, those with $^{* *}$ are significant at the $5 \%$ and those with * are significant at the $10 \%$. 
Table 3: GMM estimates of the effect of interdiction on cultivation, variables in logs

\begin{tabular}{|c|c|c|c|c|c|c|}
\hline \multicolumn{7}{|c|}{ Dependent variable: Log(Hectares of coca cultivation) } \\
\hline & (1) & (2) & (3) & (4) & $(5)$ & (6) \\
\hline $\begin{array}{l}\text { Log(Number of coca processing facilities } \\
\text { destroyed at } t \text { ) }\end{array}$ & -0.014 & & & & & $\begin{array}{l}-0.076 \\
(0.091)\end{array}$ \\
\hline $\begin{array}{l}\text { Log(Number of coca processing facilities } \\
\text { destroyed at } t-1)\end{array}$ & $\begin{array}{c}0.130 \\
(0.102)\end{array}$ & & & & & $\begin{array}{l}-0.320^{*} \\
(0.183)\end{array}$ \\
\hline $\begin{array}{l}\text { Log(Number of coca processing facilities } \\
\text { destroyed at } t-2 \text { ) }\end{array}$ & $\begin{array}{c}-0.245^{* * *} \\
(0.091)\end{array}$ & & & & & $\begin{array}{c}0.067 \\
(0.204)\end{array}$ \\
\hline $\log$ (Seizures of coca base (in $\mathrm{kg}$ ) at $\mathrm{t}$ & & $\begin{array}{l}-0.029 \\
(0.044)\end{array}$ & & & $\begin{array}{c}-0.277^{* * *} \\
(0.084)\end{array}$ & $\begin{array}{c}-0.263^{* * *} \\
(0.095)\end{array}$ \\
\hline $\log ($ Seizures of coca base (in $\mathrm{kg}$ ) at $\mathrm{t}-1$ ) & & $\begin{array}{l}-0.076 \\
(0.074)\end{array}$ & & & $\begin{array}{c}0.047 \\
(0.072)\end{array}$ & $\begin{array}{c}0.038 \\
(0.100)\end{array}$ \\
\hline $\log ($ Seizures of coca base (in $\mathrm{kg}$ ) at $\mathrm{t}-2$ ) & & $\begin{array}{c}0.001 \\
(0.057)\end{array}$ & & & $\begin{array}{c}-0.212^{* * *} \\
(0.075)\end{array}$ & $\begin{array}{c}-0.289 * * * \\
(0.075)\end{array}$ \\
\hline $\log ($ Seizures of coca leaves (in $\mathrm{kg}$ ) at $\mathrm{t}$ ) & & & $\begin{array}{c}0.056 \\
(0.041)\end{array}$ & & $\begin{array}{c}0.207^{* * *} \\
(0.044)\end{array}$ & $\begin{array}{c}0.191^{* * *} \\
(0.063)\end{array}$ \\
\hline $\log$ (Seizures of coca leaves (in $\mathrm{kg}$ ) at $\mathrm{t}-1$ ) & & & $\begin{array}{c}-0.142^{* * *} \\
(0.039)\end{array}$ & & $\begin{array}{l}-0.021 \\
(0.041)\end{array}$ & $\begin{array}{l}0.047 \\
(0.056)\end{array}$ \\
\hline $\log$ (Seizures of coca leaves (in $\mathrm{kg}$ ) at $\mathrm{t}-2$ ) & & & $\begin{array}{c}0.038 \\
(0.047)\end{array}$ & & $\begin{array}{l}-0.019 \\
(0.042)\end{array}$ & $\begin{array}{c}0.077 \\
(0.063)\end{array}$ \\
\hline $\log ($ Seizures of cocaine (in $\mathrm{kg}$ ) at $\mathrm{t}$ ) & & & & $\begin{array}{l}-0.095 \\
(0.103)\end{array}$ & $\begin{array}{l}0.048 \\
(0.078)\end{array}$ & $\begin{array}{l}-0.067 \\
(0.095)\end{array}$ \\
\hline $\log$ (Seizures of cocaine (in $\mathrm{kg}$ ) at $\mathrm{t}-1$ ) & & & & $\begin{array}{c}-0.249^{* * *} \\
(0.092)\end{array}$ & $\begin{array}{l}-0.018 \\
(0.086)\end{array}$ & $\begin{array}{l}-0.017 \\
(0.097)\end{array}$ \\
\hline $\log$ (Seizures of cocaine (in $\mathrm{kg}$ ) at $\mathrm{t}-2$ ) & & & & $\begin{array}{l}-0.083 \\
(0.077)\end{array}$ & $\begin{array}{c}0.133 \\
(0.101)\end{array}$ & $\begin{array}{c}0.076 \\
(0.108)\end{array}$ \\
\hline Log(Aerial spraying) & $\begin{array}{l}-0.035 \\
(0.033)\end{array}$ & $\begin{array}{c}0.088^{* *} \\
(0.044)\end{array}$ & $\begin{array}{l}-0.011 \\
(0.032)\end{array}$ & $\begin{array}{l}-0.055 \\
(0.065)\end{array}$ & $\begin{array}{l}-0.030 \\
(0.038)\end{array}$ & $\begin{array}{l}-0.060 \\
(0.049)\end{array}$ \\
\hline Log(Manual eradication) & $\begin{array}{c}0.014 \\
(0.040)\end{array}$ & $\begin{array}{l}-0.045 \\
(0.046)\end{array}$ & $\begin{array}{c}-0.087^{*} \\
(0.048)\end{array}$ & $\begin{array}{c}0.053 \\
(0.088)\end{array}$ & $\begin{array}{c}0.013 \\
(0.048)\end{array}$ & $\begin{array}{c}-0.008 \\
(0.056)\end{array}$ \\
\hline $\log ($ Hectares of coca cultivation at $\mathrm{t}-1)$ & $\begin{array}{c}0.686^{* * *} \\
(0.063) \\
\end{array}$ & $\begin{array}{c}0.034 \\
(0.136) \\
\end{array}$ & $\begin{array}{c}0.650^{* * *} \\
(0.116) \\
\end{array}$ & $\begin{array}{c}0.496^{* * *} \\
(0.119) \\
\end{array}$ & $\begin{array}{c}0.757^{* * *} \\
(0.078) \\
\end{array}$ & $\begin{array}{c}0.880^{* * *} \\
(0.086) \\
\end{array}$ \\
\hline Municipality FE & Yes & Yes & Yes & Yes & Yes & Yes \\
\hline Year FE & Yes & Yes & Yes & Yes & Yes & Yes \\
\hline Observations & 17,629 & 17,629 & 17,629 & 17,629 & 17,629 & 17,629 \\
\hline Number of municipalities & 1,103 & 1,103 & 1,103 & 1,103 & 1,103 & 1,103 \\
\hline Hansen test p-value & 0.308 & 0.157 & 0.146 & 0.176 & 0.142 & 0.413 \\
\hline
\end{tabular}

Notes: $\log (x)$ corresponds to the natural logarithm of $x+1$, in order to avoid indetermination whenever $x=0$. Robust standard errors in parentheses. Estimates with ${ }^{* * *}$ are significant at the $1 \%$, those with ${ }^{* *}$ are significant at the $5 \%$ and those with * are significant at the $10 \%$. 
Table 4: GMM estimates of the effect of interdiction on cultivation for 1999 coca municipalities

\begin{tabular}{|c|c|c|c|c|c|c|}
\hline \multicolumn{7}{|c|}{ Dependent variable: Hectares of coca cultivation } \\
\hline & $(1)$ & (2) & (3) & (4) & (5) & (6) \\
\hline $\begin{array}{l}\text { Number of coca processing facilities } \\
\text { destroyed at } t\end{array}$ & $\begin{array}{c}6.830 \\
(5.136)\end{array}$ & & & & & $\begin{array}{l}-1.099 \\
(4.415)\end{array}$ \\
\hline $\begin{array}{l}\text { Number of coca processing facilities } \\
\text { destroyed at } t-1\end{array}$ & $\begin{array}{c}-11.512^{* * *} \\
(2.124)\end{array}$ & & & & & $\begin{array}{c}-9.196^{* *} \\
(3.908)\end{array}$ \\
\hline $\begin{array}{l}\text { Number of coca processing facilities } \\
\text { destroyed at } t-2\end{array}$ & $\begin{array}{l}-5.667 \\
(4.239)\end{array}$ & & & & & $\begin{array}{l}-2.601 \\
(6.130)\end{array}$ \\
\hline Seizures of coca base (in $\mathrm{kg}$ ) at $\mathrm{t}$ & & $\begin{array}{l}-0.032 \\
(0.057)\end{array}$ & & & $\begin{array}{l}-0.057 \\
(0.075)\end{array}$ & $\begin{array}{l}-0.047 \\
(0.119)\end{array}$ \\
\hline Seizures of coca base (in $\mathrm{kg}$ ) at $\mathrm{t}-1$ & & $\begin{array}{c}0.018 \\
(0.069)\end{array}$ & & & $\begin{array}{c}0.068 \\
(0.064)\end{array}$ & $\begin{array}{c}0.072 \\
(0.072)\end{array}$ \\
\hline Seizures of coca base (in $\mathrm{kg}$ ) at $\mathrm{t}-2$ & & $\begin{array}{l}-0.124 \\
(0.095)\end{array}$ & & & $\begin{array}{l}-0.079 \\
(0.064)\end{array}$ & $\begin{array}{l}-0.083 \\
(0.096)\end{array}$ \\
\hline Seizures of coca leaves (in $\mathrm{kg}$ ) at $\mathrm{t}$ & & & $\begin{array}{c}0.006 \\
(0.007)\end{array}$ & & $\begin{array}{c}0.008 \\
(0.012)\end{array}$ & $\begin{array}{c}0.015 \\
(0.012)\end{array}$ \\
\hline Seizures of coca leaves (in $\mathrm{kg}$ ) at $\mathrm{t}-1$ & & & $\begin{array}{l}-0.013^{*} \\
(0.007)\end{array}$ & & $\begin{array}{c}0.000 \\
(0.004)\end{array}$ & $\begin{array}{c}0.008 \\
(0.008)\end{array}$ \\
\hline Seizures of coca leaves (in $\mathrm{kg}$ ) at $\mathrm{t}-2$ & & & $\begin{array}{c}-0.014^{* *} \\
(0.006)\end{array}$ & & $\begin{array}{c}-0.014^{* *} \\
(0.006)\end{array}$ & $\begin{array}{l}-0.006 \\
(0.007)\end{array}$ \\
\hline Seizures of cocaine (in $\mathrm{kg}$ ) at $\mathrm{t}$ & & & & $\begin{array}{l}0.042^{*} \\
(0.024)\end{array}$ & $\begin{array}{l}0.114^{*} \\
(0.065)\end{array}$ & $\begin{array}{c}0.102 \\
(0.071)\end{array}$ \\
\hline Seizures of cocaine (in $\mathrm{kg}$ ) at $\mathrm{t}-1$ & & & & $\begin{array}{c}-0.107^{* * *} \\
(0.015)\end{array}$ & $\begin{array}{c}-0.115^{* * *} \\
(0.020)\end{array}$ & $\begin{array}{c}-0.099^{* * *} \\
(0.036)\end{array}$ \\
\hline Seizures of cocaine (in $\mathrm{kg}$ ) at $\mathrm{t}-2$ & & & & $\begin{array}{c}0.024 \\
(0.044)\end{array}$ & $\begin{array}{l}0.051^{*} \\
(0.027)\end{array}$ & $\begin{array}{l}0.055^{*} \\
(0.029)\end{array}$ \\
\hline Aerial spraying & $\begin{array}{c}-0.147^{* * *} \\
(0.046)\end{array}$ & $\begin{array}{c}-0.111 \\
(0.068)\end{array}$ & $\begin{array}{l}-0.099 \\
(0.157)\end{array}$ & $\begin{array}{l}-0.095^{*} \\
(0.051)\end{array}$ & $\begin{array}{l}-0.086 \\
(0.085)\end{array}$ & $\begin{array}{l}-0.087 \\
(0.078)\end{array}$ \\
\hline Manual eradication & $\begin{array}{c}-0.124^{* * *} \\
(0.031)\end{array}$ & $\begin{array}{l}-0.080 \\
(0.050)\end{array}$ & $\begin{array}{c}-0.102^{*} \\
(0.057)\end{array}$ & $\begin{array}{l}-0.089 \\
(0.074)\end{array}$ & $\begin{array}{c}-0.050 \\
(0.067)\end{array}$ & $\begin{array}{l}-0.102 \\
(0.063)\end{array}$ \\
\hline Hectares of coca cultivation at $\mathrm{t}-1$ & $\begin{array}{c}0.847^{* * *} \\
(0.056)\end{array}$ & $\begin{array}{c}0.846^{* * *} \\
(0.061)\end{array}$ & $\begin{array}{c}0.682^{* * *} \\
(0.104)\end{array}$ & $\begin{array}{c}0.929^{* * *} \\
(0.091)\end{array}$ & $\begin{array}{c}0.654^{* * *} \\
(0.110)\end{array}$ & $\begin{array}{c}0.692^{* * *} \\
(0.091)\end{array}$ \\
\hline Municipality FE & Yes & Yes & Yes & Yes & Yes & Yes \\
\hline Year FE & Yes & Yes & Yes & Yes & Yes & Yes \\
\hline Observations & 1,456 & 1,456 & 1,456 & 1,456 & 1,456 & 1,456 \\
\hline Number of municipalities & 91 & 91 & 91 & 91 & 91 & 91 \\
\hline Hansen test p-value & 0.340 & 0.192 & 0.341 & 0.434 & 0.787 & 0.783 \\
\hline
\end{tabular}

Notes: Robust standard errors in parentheses. Estimates with ${ }^{* * *}$ are significant at the $1 \%$, those with $^{* *}$ are significant at the $5 \%$ and those with ${ }^{*}$ are significant at the $10 \%$. 
Table 5: Substitutability/complementarity of strategies

\begin{tabular}{|c|c|c|c|c|}
\hline \multicolumn{5}{|c|}{ Dependent variable: Hectares of coca cultivation } \\
\hline & $(1)$ & (2) & $(3)$ & $(4)$ \\
\hline \multirow[t]{2}{*}{ Int at $\mathrm{t}$} & 4.278 & $-0.233^{* *}$ & 0.032 & 0.045 \\
\hline & $(4.501)$ & $(0.107)$ & $(0.023)$ & $(0.028)$ \\
\hline \multirow[t]{2}{*}{ Int at $\mathrm{t}-1$} & $-9.438^{*}$ & -0.047 & -0.013 & $-0.114^{* * *}$ \\
\hline & $(5.637)$ & $(0.108)$ & $(0.023)$ & $(0.028)$ \\
\hline \multirow[t]{2}{*}{ Int at $\mathrm{t}-2$} & -0.650 & -0.115 & $-0.032^{*}$ & 0.073 \\
\hline & $(6.677)$ & $(0.185)$ & $(0.018)$ & $(0.054)$ \\
\hline Int at $\mathrm{t} \times$ Aerial & -0.000 & 0.000 & 0.000 & 0.000 \\
\hline spraying at $\mathrm{t}$ & $(0.001)$ & $(0.000)$ & $(0.000)$ & $(0.000)$ \\
\hline Int at $\mathrm{t}-1 \times$ Aerial & 0.000 & 0.000 & -0.000 & 0.000 \\
\hline spraying at t-1 & $(0.001)$ & $(0.000)$ & $(0.000)$ & $(0.000)$ \\
\hline Int at t- $2 \times$ Aerial & -0.000 & -0.000 & 0.000 & -0.000 \\
\hline spraying at t-2 & $(0.001)$ & $(0.000)$ & $(0.000)$ & $(0.000)$ \\
\hline Int at $\mathrm{t} \times$ Manual & $-0.003^{* *}$ & 0.000 & -0.000 & 0.000 \\
\hline eradication at $\mathrm{t}$ & $(0.001)$ & $(0.000)$ & $(0.000)$ & $(0.000)$ \\
\hline Int at t- $1 \times$ Manual & $0.003^{*}$ & 0.000 & $0.000^{*}$ & -0.000 \\
\hline eradication at t-1 & $(0.001)$ & $(0.000)$ & $(0.000)$ & $(0.000)$ \\
\hline Int at t- $2 \times$ Manual & -0.001 & 0.000 & $0.000^{* *}$ & 0.000 \\
\hline eradication at t-2 & $(0.001)$ & $(0.000)$ & $(0.000)$ & $(0.000)$ \\
\hline Municipality FE & Yes & Yes & Yes & Yes \\
\hline Year FE & Yes & Yes & Yes & Yes \\
\hline Observations & 17,629 & 17,629 & 17,629 & 17,629 \\
\hline Number of municipalities & 1,103 & 1,103 & 1,103 & 1,103 \\
\hline Hansen test p-value & 0.066 & 0.080 & 0.225 & 0.116 \\
\hline
\end{tabular}

Notes: Robust standard errors in parentheses. Estimates with ${ }^{* * *}$ are significant at the $1 \%$, those with ${ }^{* *}$ are significant at the $5 \%$ and those with * are significant at the $10 \%$. In column (1), 'Int' is number of cocaine processing facilities destroyed. In column (2), 'Int' is seizures of coca base. In column (3), 'Int' is seizures of coca leaves. In column (4), 'Int' is seizures of cocaine. 
Table 6: Placebo test: Effect of future interdiction on cultivation

\begin{tabular}{lcccccc}
\hline \hline Dependent variable: Hectares of coca cultivation & & & & \\
\hline & $(1)$ & $(2)$ & $(3)$ & $(4)$ & $(5)$ & $(6)$ \\
\hline Number of coca processing facilities & 0.628 & & & & & -0.414 \\
destroyed at t+1 & $(3.267)$ & & & & & $(3.935)$ \\
Seizures of coca base (in kg) at $\mathrm{t}+1$ & & -0.076 & & & -0.054 & -0.053 \\
& & $(0.060)$ & & & $(0.051)$ & $(0.052)$ \\
Seizures of coca leaves (in kg) at t+1 & & & 0.011 & & $0.013^{*}$ & 0.014 \\
& & & $(0.008)$ & & $(0.007)$ & $(0.015)$ \\
Seizures of cocaine (in kg) at t+1 & & & & 0.034 & 0.029 & 0.029 \\
& & & & $(0.022)$ & $(0.018)$ & $(0.018)$ \\
\hline Municipality FE & Yes & Yes & Yes & Yes & Yes & Yes \\
Year FE & Yes & Yes & Yes & Yes & Yes & Yes \\
\hline Observations & 17,625 & 17,625 & 17,625 & 17,625 & 17,625 & 17,625 \\
Number of municipalities & 1,103 & 1,103 & 1,103 & 1,103 & 1,103 & 1,103 \\
Hansen test p-value & 0.091 & 0.138 & 0.129 & 0.118 & 0.124 & 0.113 \\
\hline \hline
\end{tabular}

Notes: Robust standard errors in parentheses. Estimates with ${ }^{* * *}$ are significant at the $1 \%$, those with $^{* *}$ are significant at the $5 \%$ and those with ${ }^{*}$ are significant at the $10 \%$. 
Table 7: Conditional differences-in-differences estimates of the presence of interdiction

\begin{tabular}{|c|c|c|c|c|c|c|c|c|}
\hline \multicolumn{9}{|c|}{ Dependent variable: Coca cultivation } \\
\hline & $(1)$ & (2) & (3) & (4) & (5) & (6) & (7) & (8) \\
\hline \multirow[t]{2}{*}{ Estimates for 2009: } & 0.0020 & 0.0029 & -0.0008 & -0.0032 & 0.0047 & 0.0032 & -0.0035 & -0.0095 \\
\hline & $(0.0035)$ & $(0.0018)$ & $(0.0032)$ & $(0.0024)$ & $(0.0062)$ & $(0.0030)$ & $(0.0040)$ & $(0.0151)$ \\
\hline \multirow[t]{2}{*}{ Estimates for 2010: } & -0.0027 & -0.0019 & -0.0043 & -0.0013 & -0.0041 & -0.0008 & -0.0079 & $-0.0610 * * *$ \\
\hline & $(0.0035)$ & $(0.0018)$ & $(0.0036)$ & $(0.0020)$ & $(0.0060)$ & $(0.0042)$ & $(0.0048)$ & $(0.0158)$ \\
\hline \multirow[t]{2}{*}{ Estimates for 2011: } & $-0.0080^{* * *}$ & $-0.0031^{*}$ & -0.0026 & -0.0020 & $-0.0128 * * *$ & $-0.0072^{* *}$ & -0.0058 & -0.0146 \\
\hline & $(0.0026)$ & $(0.0018)$ & $(0.0030)$ & $(0.0022)$ & $(0.0045)$ & $(0.0031)$ & $(0.0037)$ & $(0.0124)$ \\
\hline \multirow[t]{2}{*}{ Estimates for 2012: } & $-0.0077^{* *}$ & $-0.0059^{* * *}$ & 0.0009 & -0.0013 & 0.0073 & $-0.0121 * * *$ & -0.0049 & 0.0133 \\
\hline & $(0.0036)$ & $(0.0021)$ & $(0.0032)$ & $(0.0018)$ & $(0.0056)$ & $(0.0031)$ & $(0.0047)$ & $(0.0083)$ \\
\hline \multirow[t]{2}{*}{ Estimates for 2013: } & $-0.0175^{* * *}$ & $-0.0123^{* * *}$ & $-0.0055^{*}$ & $-0.0082^{* * *}$ & $-0.0269 * * *$ & $-0.0187 * * *$ & $-0.0085^{* *}$ & -0.0068 \\
\hline & $(0.0030)$ & $(0.0019)$ & $(0.0032)$ & $(0.0016)$ & $(0.0050)$ & $(0.0047)$ & $(0.0043)$ & $(0.0067)$ \\
\hline \multirow[t]{2}{*}{ Estimates for 2014: } & $-0.0091^{* *}$ & $-0.0057 * * *$ & -0.0048 & $-0.0065^{* * *}$ & $-0.0194^{* * *}$ & $-0.0111^{* * *}$ & -0.0058 & $-0.0086^{* *}$ \\
\hline & $(0.0040)$ & $(0.0014)$ & $(0.0037)$ & $(0.0016)$ & $(0.0048)$ & $(0.0026)$ & $(0.0042)$ & $(0.0044)$ \\
\hline \multirow[t]{2}{*}{ Estimates for 2015: } & $-0.0209 * * *$ & $-0.0086^{* * *}$ & -0.0072 & $-0.0058^{* * *}$ & $-0.0292 * * *$ & $-0.0059^{*}$ & $-0.0223^{* *}$ & $-0.0316^{*}$ \\
\hline & $(0.0041)$ & $(0.0014)$ & $(0.0048)$ & $(0.0016)$ & $(0.0078)$ & $(0.0031)$ & $(0.0092)$ & $(0.0184)$ \\
\hline \multirow[t]{2}{*}{ Estimates for 2016: } & -0.0046 & $-0.0043^{* * *}$ & -0.0034 & $-0.0032^{* * *}$ & 0.0040 & $-0.0096^{* * *}$ & 0.134 & $0.0297^{* * *}$ \\
\hline & $(0.0045)$ & $(0.0010)$ & $(0.0055)$ & $(0.0017)$ & $(0.0104)$ & $(0.0023)$ & $(0.0110)$ & $(0.0135)$ \\
\hline \multirow[t]{2}{*}{ Estimates for 2017: } & 0.0006 & $-0.0041 * * *$ & 0.0002 & $-0.0073^{* * *}$ & 0.0103 & $-0.0085^{* * *}$ & 0.0002 & $-0.0175^{* * *}$ \\
\hline & $(0.0054)$ & $(0.0010)$ & $(0.0060)$ & $(0.0017)$ & $(0.0118)$ & $(0.0020)$ & $(0.0077)$ & $(0.0057)$ \\
\hline Estimation methodology & OLS & PSM & OLS & PSM & OLS & PSM & OLS & PSM \\
\hline
\end{tabular}

Notes: The table reports conditional differences-in differences estimates of the effect of the presence of interdiction on coca cultivation. Odd columns report usual linear regressions (i.e., assuming that conditional expectation of the outcome is linear in the covariates); even columns report matching estimates. Columns (1) and (2) report estimates for cocaine processing facilities destroyed; columns (3) and (4) report estimates for coca base seizures; columns (5) and (6) report estimates for seizures of coca leaves; and columns (7) and (8) report estimates for cocaine seizures. Robust standard errors are reported in parentheses (nevertheless, they are estimated assuming that the propensity score is known). Estimates with ${ }^{* * *}$ are significant at the $1 \%$, those with ${ }^{* *}$ are significant at the $5 \%$ and those with * are significant at the $10 \%$. 